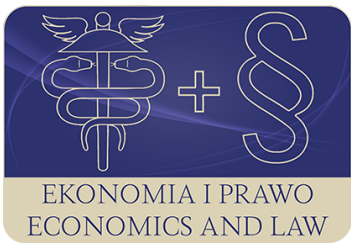

EKONOMIA I PRAWO. ECONOMICS AND LAW

Volume 15, Issue 3, September 2016

p-ISSN 1898-2255, e-ISSN 2392-1625

www.economicsandlaw.pl

EKONOMIA I PRAWO
ECONOMICS AND LAW

ORIGINAL ARTICLE

received 21.10.2015; revised 19.06.2016; accepted 30.09.2016

Citation: Fiedorczuk, M., \& Grabowiecki, J. (2016). Economic and financial crises and changes in corporate governance in Russia (Part 1). Ekonomia i Prawo. Ecomomics and Law, 15(3): 295-305. doi:10.12775/EiP.2016.019.

\title{
Economic and financial crises and changes in corporate governance in Russia (Part 1)
}

\author{
MONIKA FIEDORCZUK \\ corresponding author \\ University of Białystok, Faculty of Economics and Management, Department of International \\ Economic Relations, ul. Warszawska 63, 15-204 Białystok, Poland \\ $\square$ monika.fiedorczuk@uwb.edu.pl

\section{JERZY GRABOWIECKI} \\ University of Białystok, Faculty of Economics and Management, Department of International \\ Economic Relations, Poland \\ $\square$ j.grabowiecki@uwb.edu.pl
}

\begin{abstract}
Motivation: Favorable conditions for the development of corporate governance in Russia emerged at the beginning of the 90s, together with the commencement of economic and political transformation. At the beginning, one of the main factors connected with building and developing a corporate governance system was the process of privatization of state-owned enterprises and main market reforms. In the subsequent years, more factors emerged, such as: further economic reforms, political transformations, adequate corporate legislation as well as financial and economic crises.

Aim: The article's main thrust is to evaluate the impact of financial crisis of 1998 on the evolution of selected internally and externally mechanisms of corporate governance in Russia.

Results: The article uses theoretical analysis method based on a survey of literature and statistical data (especially from Russian Federal Statistics Service). The authors assume that the financial crisis of 1998 was a turning-point in the process of the evolution of corporate governance system in Russia. The crisis gave rise to new process of redistribution and consolidation of the ownership, caused significant changes in ownership structure and the process of building the new type of business groups (holdings). It caused the sig-
\end{abstract}


nificant development of the corporate control market (mergers and acquisitions) as well as changes in the bankruptcy law.

Keywords: ownership structure; state; corporate control; economic and financial crises JEL: G32; G34

\section{Introduction}

The actual operation of the corporate governance system in particular countries reveals a variety of solutions emerging from specific economic, political, legal, historic or cultural conditions. They result in a particular combination of internal and external mechanisms as well as supervisory institutions. National systems, in spite of a long development period, do not constitute a static structure. They undergo gradual changes due to certain economic and political events as well as undertaken legal solutions.

The analysis of changes in the Russian economy from the late 80s of the XX century until now enables the distinction of the main stages of economic transformation as well as the formation of the corporate governance system. The authors claim that economic and financial crises were the key contributors to the transformation of the corporate governance system in Russia. They invoked changes in many supervisory mechanisms.

The main aim of this part of article is to analyse the impact of financial crisis of 1998 on the changes in the selected corporate governance mechanisms in Russia. The research was conducted, most of all, on the basis of the analyses performed by the leading Russian research centers and statistical data.

\section{The state of knowledge}

\subsection{Corporate governance in Russia before the 1998 crisis}

The transformation program in Russia concerned economic liberalization, macroeconomic stabilization as well as privatization, which in the early stage became the decisive factor influencing the work of Russian enterprises (Ясин, 1993, p. 128). 3 July 1991 is treated as a contractual beginning of privatization period in Russia, when the Supreme Soviet of the Russian Federation passed an act on 'Privatization of State and Municipal Enterprises of the Union of Soviet Socialist Republics (USSR). The three types of privatizations, which were to be implemented for the state-owned enterprises, were distinguished: a small privatization, a large-scale privatization as well as a voucher privatization.

The suggested ways of privatizing medium and big enterprises granted exceptional privileges for employees and managers. First official research connected with ownership structure of 1000 Russian companies was conducted as early as in the middle of 1994 by the Russian Marketing Association (Радыгин et at., 1995, p. 51). In the examined companies about $66 \%$ of stocks went into 
the hands of the insiders (ordinary employees and managers). Other research into ownership structure of Russian companies confirmed those results ${ }^{1}$. The initial ownership structure was described as insider and scattered due to the fact that the majority of stocks in many companies went into the hands of ordinary workers (Долгопятова, 2010, p. 82). Along with the termination of voucher privatization (since 1995) it could be noticed that the participation of ordinary employees was greatly reduced for the benefit of managers as well as outsiders. Concentration of ownership also appeared. The group which benefited mostly in the stage under consideration was the one composed of directors and managers of the privatized enterprises (Радыгин, 1999b, pp. 54-55).

The state was an important participant of the corporate governance system in the mid 90s, despite privatizations. The state at various levels (federal, regional and municipal) kept ownership in enterprises within the so-called security interests, golden share or residual interests, which did not find a private owner (Мальгинов \& Радыгин, 2007).

In the first years of developing the corporate governance system, the institutions that played a crucial role were also banks. Their position resulted mostly from their legal ability to participate in the so-called loans for shares, which caused that by the end of 1995 the group of leading and financially strong banks became the owner of the controlling interests of big industrial enterprises (Яковлев \& Данилов, 2007, p. 11).

In the first years of transformation, the external corporate governance mechanisms played a secondary role in the Russian economy. Until 1998, the transactions of mergers and acquisitions were relatively rare and were performed mainly by banks which were developing their financial-industrial groups (FIGs) (Радыгин, 1999a, p. 95). Capital market, which started its development in 1992, played a marginal role in the corporate governance system until the crisis of $1998^{2}$.

\subsection{Financial crisis of 1998}

The first years of dynamic transformation in Russia were interrupted with the August 1998 financial crisis. It was mainly caused by an expansive budgetary and exchange rate policy conducted by the government in 1994-1997. In the middle of the 90s, the Russian government resigned from financing the budget deficit with credits obtained from the Central Bank of the Russian Federation and focused on covering deficit with securities (Гайдар, 1999, pp. 7-11). Lack of consistency in reforming the expenditure part of the budget, a 'soft' fiscal policy and high interest rates (to increase demand for state se-

${ }^{1}$ For example: Russian Economic Barometer (е.g. Аукуционек et al., 1998), Institute for Market and Industrial Studies (е.g. Долгопятова, 2001).

2 Among more than 50 thousand of open joint-stock companies operating in Russia (including about 30 thousand of comapnies set up in the privatization process), only up to about 300 enterprises were listed on stock exchanges until the crisis. 
curities), caused the growth of state debt, which escalated the dependence of the economy from the economic situation on the raw material and financial markets and from the success of external creditors.

The signs of the incoming crisis could be seen in the economy as early as in the second part of 1997. In that year, the internal debt of the country doubled, compared to the previous year (from almost 190 to 365 bln USD). Only the debt in securities increased from 85.2 to almost 250 bln USD. The increasing debt led to the growth of absolute and relative costs of its service. They tripled from 1996 to 1997 - from 38.2 to 105.7 bln USD. The upward trend in the analyzed period related also to the foreign debt (Гайдар, 1999, pp. 26-27).

The culmination of the Russian crisis were the resolutions of the Russian Federation government and the Central Bank adopted on 17 September 1998. They were composed of three points (Илларионов, 1999, p. 5):

- changes of exchange rate: from 5.25-7.15 ruble for 1 dollar to the level 6.09.5 ruble for 1 dollar (in practice devaluation of Russian ruble);

- suspending the service of short-term bonds, next, the cessation of trading in them and their restructuring;

- announcing the 90-day moratorium on the service of external debts by Russian private companies and banks.

The crisis caused a considerable loss of either external and internal confidence of investors in the government, the Central Bank and the Ministry of Finance, which meant losing the possibility of gaining financial means and could lead to the outflow of capital abroad and consequently bring the necessity of turning to inflationary deficit financing. There was a fall in the Russian stock exchange, which limited the possibility to attract portfolio investments by public companies. The events in the second half of 1998 indicated negative changes for the banking sector in Russia. Many banks, which were central subjects for FIGs, went bankrupt (Паппе, 2002, p. 35).

The immediate effect of the crisis was a significant deterioration of the most important macroeconomic indicators (chart 1). In 1998, the Russian economy noted, among others, the drop in Gross Domestic Product (GDP), industrial production, investments and the foreign trade turnover (the biggest fall), which was caused mainly by the decrease in the ruble exchange rate as well as by unfavourable economic situation on foreign markets following the Asian crisis of 1997.

\section{The methodology of research}

The period of analysis is 1998-2008, divided into two distinct period separated by the financial crisis of 1998 in Russian economy: from the beginning of the transformation process and after the crisis of 1998. The paper uses the method of analysis of both the scientific literature and the statistical data. To achieve the goal formulated in the article, the comprehensive and critical literature studies and an analysis of statistical data was conducted. 
The research was conducted, most of all, on the basis of the analyses performed by the leading Russian research centers, including Institute for Industrial and Market Studies (Higher School of Economics in Moscow), Gaidar Institute for Economic Policy in Moscow, Russian Economic Barometer, National Council of Corporate Governance. Furthermore, the data collected from the Russian Federal State Statistics Service (Rosstat) and mergers.ru portal (which deals with analyzing the transactions of companies' takeovers in Russia) was used. The article constitutes a part of a broader research project, which aims at characterizing the evolution of the Russian corporate governance system.

\section{The research process and the results of analysis}

\subsection{Changes in ownership structure}

The crisis opened a new stage of changes in ownership structure of Russian companies. The main trends in the field of redistribution of ownership were the result of a considerable deterioration in the situation of the Russian banking system. The bankruptcy of many banks and financial difficulties of those that survived the crisis led to the relocation of the assets of industrial enterprises into the hands of holding companies and other integrated corporate structures. Moreover, the decrease in the value of shares of many companies listed on the stock exchange as well as a difficult situation of companies focused mainly on activities connected with trade and finance and, on the other hand, devaluation of the ruble and increase in export competitiveness, initiated the dynamic development of industrial sector, especially within the business groups (Яковлев \& Данилов, 2007, p. 12).

The process of ownership redistribution after the crisis was very intense and it affected almost every asset accumulated before the actual economic transformation ${ }^{3}$. It was characterized mainly by a drop in participation of insiders (mostly employees) in ownership and increase in outsiders' share (resulting among others from a significant decline in the companies' share value). The participation of managers increased, although it was not always backed with official statistical data, among others, due to extension of informal control carried out by managers - through buying or transferring shares to the companies connected with them, which statistically meant the increased participation of companies in ownership.

3 According to research results of the Russian Economic Barometer as well as the Institute for Industrial and Market Studies (IIMS) by the end of the 90s and at the beginning of the previous decade, the change of the main owners concerned on average about $6-8 \%$ of joint-stock companies every year and according to the research results of the IIMS in the years 2001-2004,30\% of joint-stock companies faced the change of the main owner (Национальный совет по корпоративному управлению, 2008, p. 24). 
The Rosstat data, concerning the structure of authorized capital of the Russian business entities from 2000 (chart 2) serves as a primary confirmation of the described trends. In the years 2000-2007, a systematic decrease in the number of natural persons participating in companies' ownership (from almost $16 \%$ in 2000 to $3.6 \%$ in 2007) could be observed. It meant, on the one hand, the falling participation of ordinary workers and, on the other hand, the transfer of companies' assets to the companies set up by managers as well as the process of assets' consolidation within the business groups. Moreover, the participation of enterprises (commercial organizations) rose from 50\% in 2000 to $77.7 \%$ in 2007 (over of the authorized capital value).

A relatively stable participation of the state in ownership should also be highlighted (at all levels), which can be explained by the integration of state ownership within the burgeoning state-owned holding companies, which developed mainly in strategic industrial branches. The policy of the state, concerning the management of state ownership, focused mainly on consolidating assets into holding companies, increasing participation in strategic enterprises to the level of controlling interest as well as on privatizing minority stakes in non-strategic sectors (Шпренгер, 2010, p. 121). The principal objective of those activities was to preserve or form, in strategic branches of the industry, at least one state 'power center' (иентра силь), created from the state-owned elements, including unitary companies and blocks of shares. New state-owned holding companies were set up and the already existing ones were being strengthened (among others Rosnieft', Rosenergoatom, Rosspirtprom, Gazprom, RAO JeES, Aeroflot).

The research results of the Russian research centers clearly confirm the systematically changing stake of ordinary workers in ownership of companies ${ }^{4}$. The changes in managers' stake were not explicit. Moreover, the research pointed at the growing participation of other enterprises in ownership, which is a sign of a developing consolidation of ownership within holding companies.

The period after the crisis of 1998 was characterized by the constantly growing level of ownership concentration. While at the end of the 90s this level reached, on average, about $30 \%$, half of the previous decade was the culminating point of ownership concentration in Russian companies, which amounted to $55 \%$, on average (Долгопятова, 2010, p. 85).

\subsection{Changes in the corporate control market}

Changes in ownership structure of Russian companies were fostered by the activation of the corporate control market. While in the mid 90s, corporate control was formed internally (among others, by transition of ownership from employees to managers) or with privatizing transactions. What came to the foreground after the crisis were the external transactions that concerned the blocks of com-

${ }^{4}$ Among others, the research of the Russian Economic Barometer, Institute for Industrial and Market Studies (Kuznetsov et al., 2008; Долгопятова, 2009). 
pany's shares (Гайдар, 2004, pp. 338-339). Main entities deciding about the dynamic development of the corporate control market were the new business groups, mainly of holding company type, which partly substituted FIGs that were actively operating before the crisis.

Since 1999, the corporate control market in Russia had been developing dynamically. The years 1999-2002 brought to the Russian economy jointly 1305 transactions from mergers and acquisitions with the total value of 34.6 bln USD (table 1). While the number of transactions increased 4.5 times in the period under consideration, their value rose almost 13 times. The average value of transactions increased from almost $12 \mathrm{mln}$ in 1999 to above $96 \mathrm{mln}$ USD in 2002.

In the analyzed period, among the Central and Eastern European countries, Russia player the leading role when it comes to the transactions from mergers and acquisitions, which jointly covered about $70 \%$ of this region's market and 2.8\% of the global market (Авдашева et al., 2007, p. 407). In 2004, the value of the transactions from mergers and acquisitions in Russia reached 9.3\% GDP (just to compare, in the United States in 2005 it was 6.6\%). National market for corporate control was characterized in 2007-2008 by much greater dynamics than the global market - compared to the year 2005, the increase in value by $112 \%$ in 2007 and $94 \%$ in 2008 (for the global market 32 and 24\% respectively) (KPMG, 2013). Very favourable economic situation on international raw materials markets definitely boosted the dynamics on the corporate control market in Russia.

\section{Conclusion}

The evolution of the corporate governance system in Russia caused that, in Russian companies, there is a dominance of internal supervisory mechanisms, mainly ownership structure, secondary role of external mechanisms, significant role of institutions, formal as well as informal and constantly the same or increasing role of the state within various mechanisms. Those features of corporate governance (besides legal, political and cultural conditions) resulted significantly from financial and economic crises, which had various grounds.

The key factor for the evolution of the corporate governance system in Russia was the financial crisis of 1998. It caused the beginning of a new stage in ownership redistribution in the Russian corporate sector, the banking sector lost the level of importance in ownership and the integration and consolidation process within the business groups (mainly holdings) began. Moreover, the crisis resulted in the increase in significance of the selected market mechanisms in the corporate governance system in Russia, including especially the corporate control market, which was mainly utilized as a tool for ownership redistribution. The state again became an active participant of the corporate sector. The positive impact of the crisis of 1998 was the improvement in corporate governance quality standards, especially due to the fact that Russian companies started 
turning towards international financial markets and that the market supervisory mechanisms started being more utilized.

\section{References}

KPMG (2013), Рынок слияний и поглощчений в России 2012 в году, Retrieved 06.08.2014 from http://www.kpmg.com/ru.

Kuznetsov, A., Kapelyushnikov R., \& Dyomina N. (2008). Performance of closely held firms in Russia: evidence from firm-level data. The European Journal of Finance, 14(4).

Авдашева, С.Б., Шаститко, А.К., \& Калмычкова, Е.Н. (2007). Экономические основы антимонопольной политики: Российская практика в контексте мирового опыта, Часть 3. Экономический журнал ВШЭ, 3.

Аукуционек, С., Жуков, В., \& Капелюшников, Р. (1998). Доминируюшие капегории собственников и их влияние на хозяйственное поведение предприятий. Вопросы экономики, 12.

Гайдар, Е. (Ed.). (1999). Российская экономика в 1998 году тенденции и nерспективы (Выпуск 20). Москва: Институт экономики переходного периода.

Гайдар, Е. (Ed.). (2004). Российская экономика в 2003 году. Тенденции и перспективы (Выпуск 25). Москва: Институт экономики переходного периода.

Долгопятова, Т. (2001). Модели и механизмы корпоративного контроля в российской промышленности. Вопросы экономики, 5.

Долгопятова, Т. (2009). Изменение структуры собственности на предприятиях обрабатывающей промышленности. Bопросы экономики, 12.

Долгопятова, Т. (2010). Концентрация собственности в российской промышленности: эволюционные изменения на микроуровне. Журнал Новой экономической ассоцииачии, 8.

Илларионов, А. (1999). Мифы и уроки августовского кризиса (часть 1). Вопросы экономики, 10.

Мальгинов, Г.Н., \& Радыгин, А.Д. (2007). Смешанная собственность в корпоративном секторе: эволючия, управление, регулирование. Москва: ИЭПП.

Национальный совет по корпоративному управлению. (2008). Национальныцй доклад по корпоративному управлению, Выпуск 1, Москва: НСКУ.

Слияния и поглощения в России (2014), Обзор российского рынка слияний и поглощсений, Retrieved 08.08.2014 from http://mergers.ru.

Паппе, Я.Ш. (2002). Российский крупный бизнес как экономический феномен: особенности становления и современного этапа развития. Проблемьl прогнозирования, 1.

Радыгин, А. (1999а). Внешние механизмы корпоративного управления и их особенности в России. Ворпосы экономики, 8. 
Радыгин, А. (1999b). Перераспределение прав собственности в постприватизационной России. Вопросы экономики, 6.

Радыгин, А., Гутник, В., \& Мальгинов, Г. (1995). Постприватизационная структура акционерного капитала и корпоративный контроль: контрреволюция управляющих. Вопросы экономики, 10 .

Федеральная служба государственной статистики. (2014). Офищиальная статистика. Retrieved 20.09.2014 from http://www.gks.ru.

Федеральная служба государственной статистики. (2015). Промышиленность России 2002, 2005, 2008, 2010, 2012, 2014. Retrieved 10.07.2015 from http://www.gks.ru.

Шпренгер, К. (2010). Государственная собственность в российской экономике. Часть 1. Масштаб и распределение по секторам. Журнал Новой экономической ассоџиации, 6.

Яковлев, А.А., \& Данилов, Ю.А. (2007). Российская корпорация на 20 -летнем горизонте: структура собственности, роль государства и корпоративное финансирование. Россуйский журнал менеджмента, 5(1).

Ясин, Е. (1993). Судьба экономической реформы в России. Вопросы экономики, 2.

\section{Acknowledgements}

Author contributions: authors have given approval to the final version of the article. Authors contributed to this work equally.

Funding: this research was fully funded by a grant (DEC-2013/11/N/HS4/03327). 


\section{Appendix}

Table 1.

The Russian corporate control market in the years 1999-2008

\begin{tabular}{ccccccccccc}
\hline Specification & 1999 & 2000 & 2001 & 2002 & 2003 & 2004 & 2005 & 2006 & 2007 & 2008 \\
\hline $\begin{array}{c}\text { Number of transactions } \\
\text { Value of transactions } \\
\text { (in bln USD) }\end{array}$ & 119 & 211 & 435 & 540 & 693 & 1228 & 1383 & 1443 & 1364 & 1302 \\
$\begin{array}{c}\text { Average value of transactions } \\
\text { (in mln USD) }\end{array}$ & 1.4 & 2.7 & 12.4 & 18.1 & 32.4 & 27.1 & 60.2 & 61.9 & 127.7 & 117.0 \\
$\begin{array}{c}\text { Relation to GDP (in \%) } \\
\text { N/A }\end{array}$ & N/A & 3.8 & 4.5 & 6.6 & 9.3 & 6.2 & 7.9 & 9.3 & 6.6 \\
\hline
\end{tabular}

Source: own preparation based on: Слияния и поглощения в России (2014).

\section{Chart 1.}

The dynamics of the basic chosen macroeconomic values in Russia in 1997-2002 (in \% compared to the previous year)

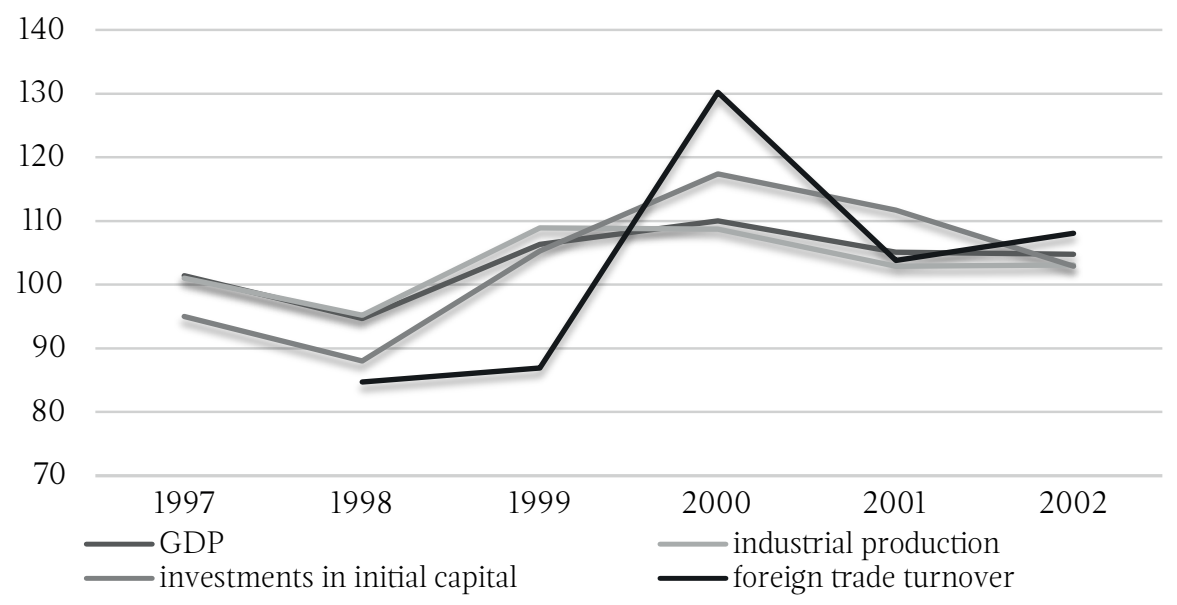

Source: own preparation based on: Федеральная служба государственной статистики (2014). 


\section{Chart 2.}

The structure of authorized capital of business entities in Russia according to shareholders in the years 2000-2007 (in \%)

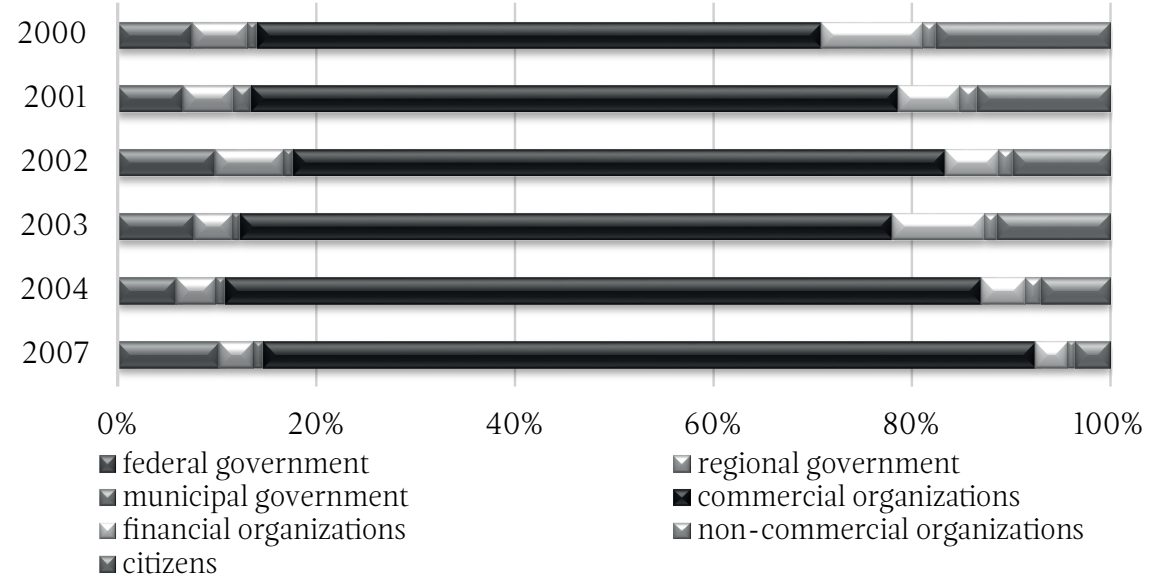

Source: own preparation based on: Федеральная служба государственной статистики (2015). 
